\title{
The Integration of Transportation Route of Industrial Area and Lurik Tourism for Production and Sales Optimization
}

\author{
G. Yudana a , I. Aliyah ${ }^{a}{ }^{*}$, R. Sugiarti ${ }^{b}$ \\ a. Department of urban and regional planning-faculty of engineering-Sebelas Maret University, Indonesia \\ b. Research and Development Centre of Tourism and Culture, Research and Community Service Institute, Sebelas Maret University, Indonesia
}

\section{Article Info:}

Received: 15 August 2019

in revised form: 10 Dec 2019

Accepted: 12 Dec 2019

Available Online: 7 April 2020

\section{Keywords:}

Transport mapping, GIS, integration of transportation route, industrial area and lurik tourism, production and sales

\section{*Corresponding Author:} Istijabatul Aliyah

Department of urban and regional planning-faculty of engineeringSebelas Maret University, Indonesia Email: istijabatul@ft.uns.ac.id

\begin{abstract}
The development of industrial and tourism areas brings the consequences of the arrangement of transportation routes. As an industrial area as well as lurik tourism, Klaten District becomes the research location to know the mapping of access and integration of industrial transportation and lurik tourism route to optimize production and sales. The method employed in this research was digital mapping through GIS, and superimposed analysis of mapping results to get integrated integration. The results reveal that transportation routes naturally form a pattern of industrial circulation with the orientation of efficiency and independence of distribution and sales of lurik products. Meanwhile, the pattern of tourism circulation is formed with the direction of interconnection between industry and tourism support facilities. Both patterns can be integrated to achieve the effectiveness of lurik industrial tourism development routes through a lurik industrial tourism concept based integration of transportation access. Integration constructed can be optimized through the implementation of thematic tourism concept by unifying smoothness, security and easy access point between lurik industry and tourism.
\end{abstract}

How to cite (APA 6th Style):

Copyright (C) 2019 GJGP-UNDIP This open access article is distributed under $a$ Creative Commons Attribution (CC-BY-NC-SA) 4.0 International license.

Yudana, G, et al. (2019). The Integration of Transportation Route of Industrial Area and Lurik Tourism for Production and Sales Optimization. Geoplanning: Journal of Geomatics and Planning, 6(2), 81-88. doi: 10.14710/geoplanning.6.2.81-88

\section{INTRODUCTION}

The trend of foreign tourist arrivals in Indonesia grew higher than three other major countries in Southeast Asia, based on foreign tourist data who visit Singapore, Malaysia, Thailand and Indonesia until June 24th, 2017. Business Times recorded foreign tourist arrivals in Singapore in the first four months in 2017 reached 5.79 million tourists. This amount got increased by 4.4 per cent year on year (YoY) compared to the previous years. Meanwhile, regarding the Xinhua page on June 8th, 2017, the trend of foreign tourist arrivals in Malaysia got decreased by 0.5 per cent year on year (YoY). However, foreign tourist arrivals in the land of white elephants, Thailand, in the first four months in 2017 reached 12.02 million. This amount improved by 2.91 per cent compared to the same period in 2016 as much as 11.68 million tourists (Jati, 2017).

Some efforts to develop tourism in ASEAN countries continue to carry out. Tourism collaboration models among ASEAN countries have given a significant contribution. One model that displays the mechanism of ASEAN tourism collaboration points out the environment where the partnership has taken place, the interactivity of various components, institutional arrangements, and feedback mechanisms between collaborative processes and collaboration preconditions (Wong et al., 2011). Besides, ASEAN Tourism Forum (ATF) is a regional effort to promote ASEAN areas as a tourism destination. This annual event involves all tourism industry sectors from 10 ASEAN countries including Brunei Darussalam, Cambodia, Indonesia, Laos, Malaysia, Myanmar, Philippines, Singapore, Thailand and Vietnam as well as three Asian countries including China, India and Korea (Prodjo, 2017).

Most ASEAN countries are developing countries. They are indicated by some characteristics including 1) high population growth rates; 2 ) high unemployment rates; 3 ) dependence on the agricultural or primary sector; 4) ineffectual markets and information; 5) low per capita income, 6) inadequate job opportunities; 7) limited business capital. Some countries in ASEAN have some areas with the uniqueness becoming a cultural 
heritage and holding a high selling power in tourism. The tourism industry is one of the sectors occupying a vital role in the development and competitiveness of various areas (Todaro \& Smith, 2012). Likewise, Alberti \& Giusti (2012) argue that the relationship between cultural heritage and regional competitiveness can be developed into cluster formation and development through tourism synergy and cultural heritage. While current research of Grodach et al. (2017) is carried out in urban areas, the result shows that cultural policy of an area can be directed to cultural industry, small manufacturing and craft-based production. In their study, it also explores the relationship among the cultural industry as a small producer, cultural productionoriented development, and the existence of manufacturing in an area.

Douglass (2016) suggests that the goal of economic growth in Asia is the emergence of a creative community in an environment based cultural and social relationship. Additionally, Richards (2011) claims that tourism development has creatively been conducted through the change of tourism orientation from cultural tourism in terms of traditional performance into tourism with daily life object in tourism destination area. The development of art-based tourism and rural community business has a potential to strengthen interactional networks and to encourage community's involvement, ownership, entrepreneurship and creative transformation (Balfour et al., 2018). It seems to reclaim statement that tourists' innovative experiences can occur due to tourists' interaction with environments, business actors, products, services, and joint activities (Tan et al., 2013).

The transition of tourism interest on rural tourism is a social representation resulted from non-tourism aspects including culturalization, creative, experience, humanization, leisure, refinement, life-orientation and characteristics (Lai et al., 2017; Wang et al., 2015). Rural tourism got admitted as a fundamental approach for rural development and poverty alleviation. Traditional Village Revitalization Model and the ideas for Sustainable Livelihoods are integrated to reveal three useful aspects in revitalizing village in terms of material, social, and spiritual (Gao \& Wu, 2017).

Many tourist attractions are recognized in rural areas having the power to bring tourists both domestic and international. A potential of rural areas in Indonesia is rural tourism with lurik product potential located in Klaten District, Centre Java Province, Indonesia. This area has become an exciting tourists' destination. Besides, various community's activities as lurik craftsperson's and lurik production process become attractions for tourists to enjoy the beauty of lurik products, to shop lurik products as well as to see lurik craftsperson's' lives directly. Thus, the rural area manufacturing lurik products in Klaten District becomes not only an industrial area but also a lurik tourism area.

The ease of access to the tourism area is part of a journey to construct and to maintain the image of tourism destination over tourists. It emphasizes the study conducted by Chen et al. (2013) that there is a significant relationship between journey restriction and the construction of tourism destination image. Consequently, to develop rural tourism needs a study which can reveal the integration of transportation routes in industrial areas and lurik tourism to optimize production and sales of lurik products. The purpose of this study is to show the integration transportation route and a pattern of tourism circulation as a contribution to rural tourism development based on craft-industry society.

\section{DATA AND METHODS}

\subsection{Study area}

This study took place at Klaten District in Centre Java Province is one of 35 districts/cities holding a strategic value and an important role in the development process of many areas in Centre Java. Klaten District area is located in a very strategic route because it is directly adjacent to the Special Region of Yogyakarta, acknowledged as one of Tourism Destination Areas (DTW). Klaten District is one of the areas having developed lurik in which the offices spread in three sub-districts including Bayat, Pedan and Cawas. A village is officially proclaimed as tourism village-based lurik products in Telingsing Village, Cawas Sub-district, Klaten District. The existence of Cawas Sub-District among other sub-districts of lurik producers in Klaten District, as shown in Figure 1. 


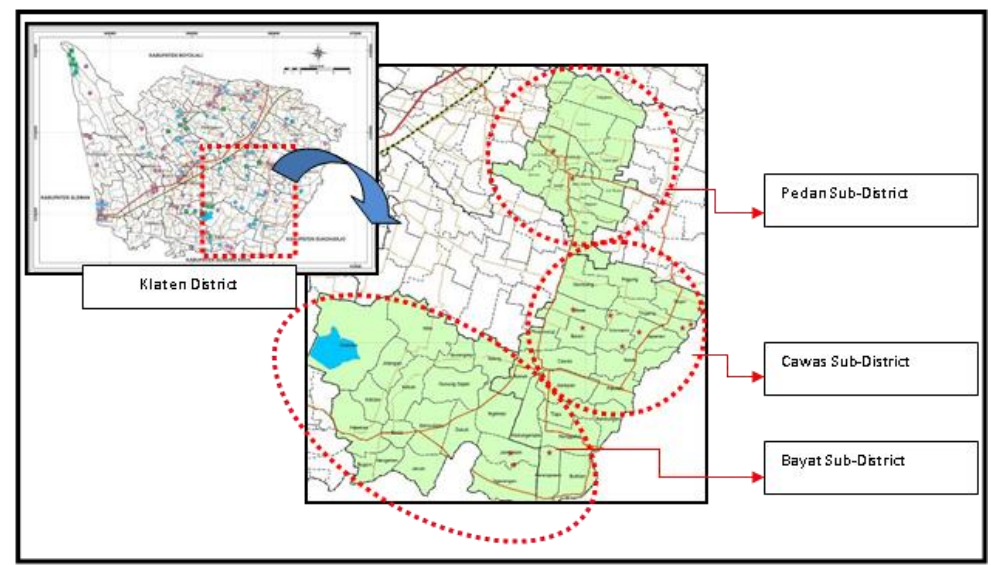

Figure 1. The existence of Cawas Sub-District toward Bayat and Pedan Sub-Districts in Klaten District

\subsection{Lurik Industrial Area}

Lurik products in Telingsing Village are products of Traditional Looms (ATBM). The craftspersons have to innovate and compete in manufacturing various ATBM lurik products with good quality and affordable price for all community levels. This is one of the unique levels by maintaining the good quality product with the economical price. The attraction of the beauty from the lines in an integrated colour arrangement with various patterns is not separated from life philosophy which is rich of meaning. Lurik is a masterpiece worthed to preserve. The development of superior lurik products is not separated from lurik potential and characteristics in each area. The distribution of lurik industry in Telingsing Village is represented in Figure 2.

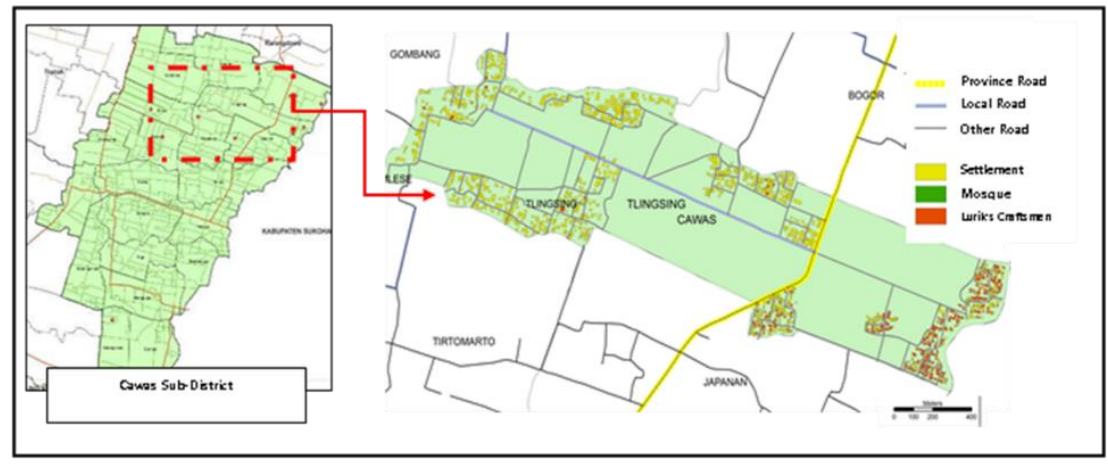

Figure 2. Map of Lurik Industry in Telingsing Village, Cawas Sub-District, Klaten District

Lurik is one of the local cultures possibly developed as an attraction of tourism areas in Klaten District. Lurik products are one of the superior products in that area. Besides, traditional lurik manufactured in Telingsing Village has become a local culture icon and local wisdom product. This is realised on the beauty of the colourful lines arranged and combined with full of harmony. Lurik is a collection of lines with cultural meaning and philosophical values which cannot be separated from tradition. Lurik is produced to wear in rituals related to belief in society. In Telingsing Village, Klaten District, there are many small industrial businesses manufacturing traditional lurik manually with using Traditional Looms (ATBM) (Figure 3). The manufacturing of lurik products is mostly carried out by craftswomen in Klaten District because traditional lurik production needs patience and carefulness, and women generally have both characters. Job opportunities in traditional lurik production can give a contribution for strengthening family's economy and encouraging local economy development. 


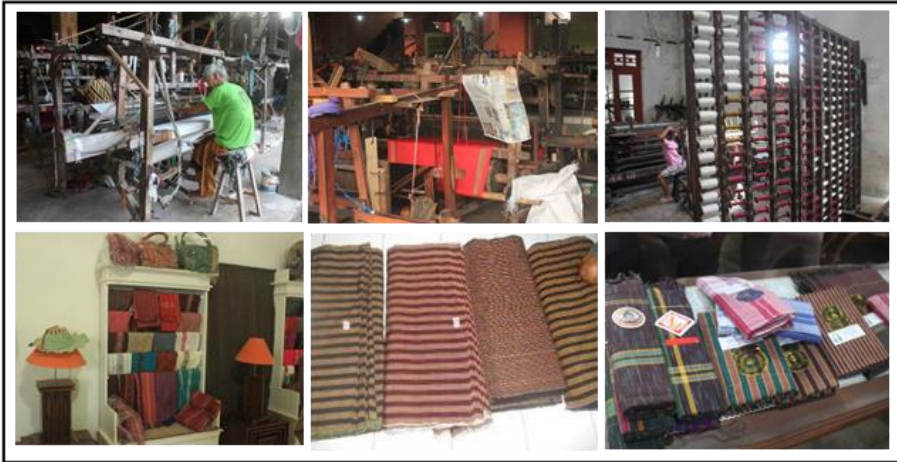

Figure 3. Lurik as a result of women's handicrafts by using Traditional Looms (ATBM) in Telingsing Village

\subsection{Lurik Tourism Region}

Tourism area is a tourism destination area containing various tourism attraction. According to Law of the Republic of Indonesia, Number 10 Year 2009 about Tourism, tourism destination area is called as a tourism destination, referring to a geographical area located in one or more administrative areas containing tourism attraction, public facilities, tourism facilities, accessibility, and community which is interrelated and complement in maintaining tourism. Tourism attraction is a driving factor for tourists to travel. These attractions can be natural resources in terms of rivers, lakes, caves, beaches, seas and forests, and can also be cultural elements including crafts, art performances, and community customs.

Meanwhile, accessibility deals with the reachability of a location or tourism attraction in accordance with physical and non-physical contexts. Physically reachability refers to physical things such as the availability of roads, bridges, local airports, local transportations, and signposts. Besides, non-physical reachability refers to non-physical things in terms of community customs in tourism location, local community's mindsets, local community's experiences in welcoming tourists arrivals before, which in turn can lead to if local community can welcome tourists' presence in their place. In a certain case, there is a phenomenon that a location or tourism attraction can physically be accessed, but it is unable to access non-physically because the local community in tourism destination area do not allow tourists arrivals. The constellation of lurik tourism area can be figured out in Figure 4 .

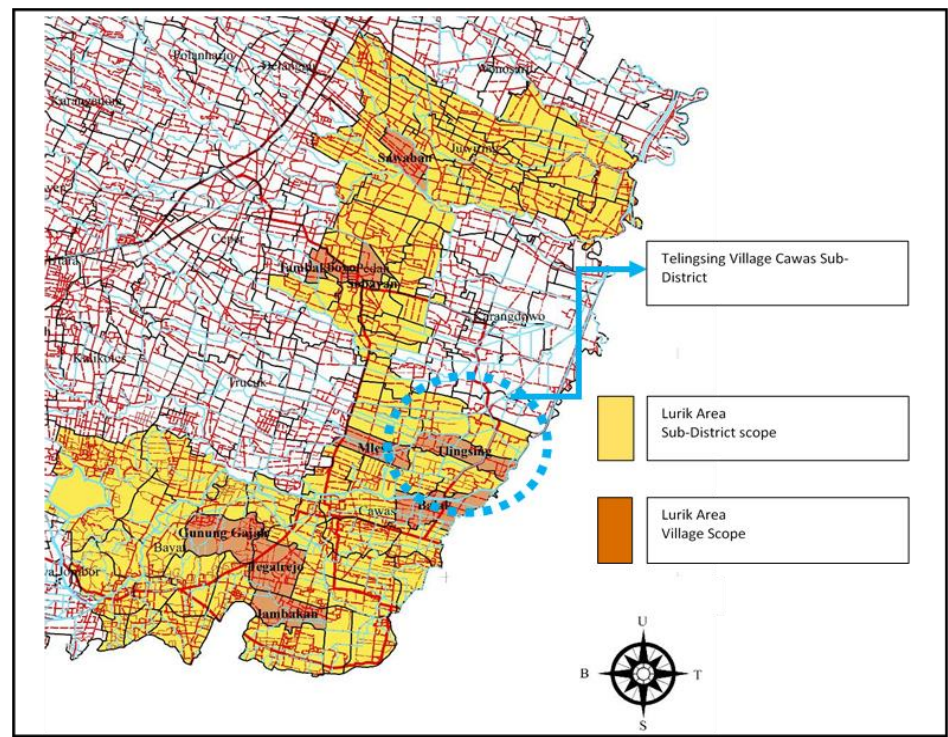

Figure 4. Transportation Route of Lurik Tourism Area in Telingsing Village, Cawas Sub-District and its surroundings in Klaten District

\subsection{The Transportation Route of Production and Sales}

The development of transportation technology and the low cost of transportation stimulates the ease to travel to both domestic and international tourism. Tourists' movement and considerably shopping activities 
have opened opportunities for each country in the world to organize each potential of Tourism Attraction Object (ODTW), so it becomes a primary destination for tourists. Lurik tourism area in Telingsing Village, Klaten District is a tourist destination which can be accessed physically and non-physically, especially transportation routes used by tourists. Transportation route of production and sales is shown in Figure $\mathbf{5}$.

\subsection{Methods}

Klaten became the research location in order to know the mapping of access and integration of industrial transportation system and lurik tourism to optimize production and sales. The method employed in this research was digital mapping with GIS, and superimpose analysis of mapping results to get integrated integration. The mapping of industrial transportation access and lurik tourism applied GIS method by tracking the location of industry and tourism, which was then assembled in a series of linkages in function and characteristics of each location and access used. The series of mapping results of industrial transportation access and lurik tourism were analyzed by superimpose analysis technique to obtain the pattern of industrial and tourism transportation system. Based on the results of the analysis, a further study of the result of integration of transportation system happening at industrial area and lurik tourism in Klaten can be conducted.

This research employed purposive sampling and snowball sampling. Purposive sampling was conducted by taking samples since the key people selected from society and government stakeholder, particularly parties involving in the tourism village development, truly comprehend the problems related to this research. On the other hand, snowball technique was used to determine informants by contacting the first key person from society and government stakeholder who were chosen and finding the next key person from the information derived from the first key person and the next, until the data needed was fulfilled.

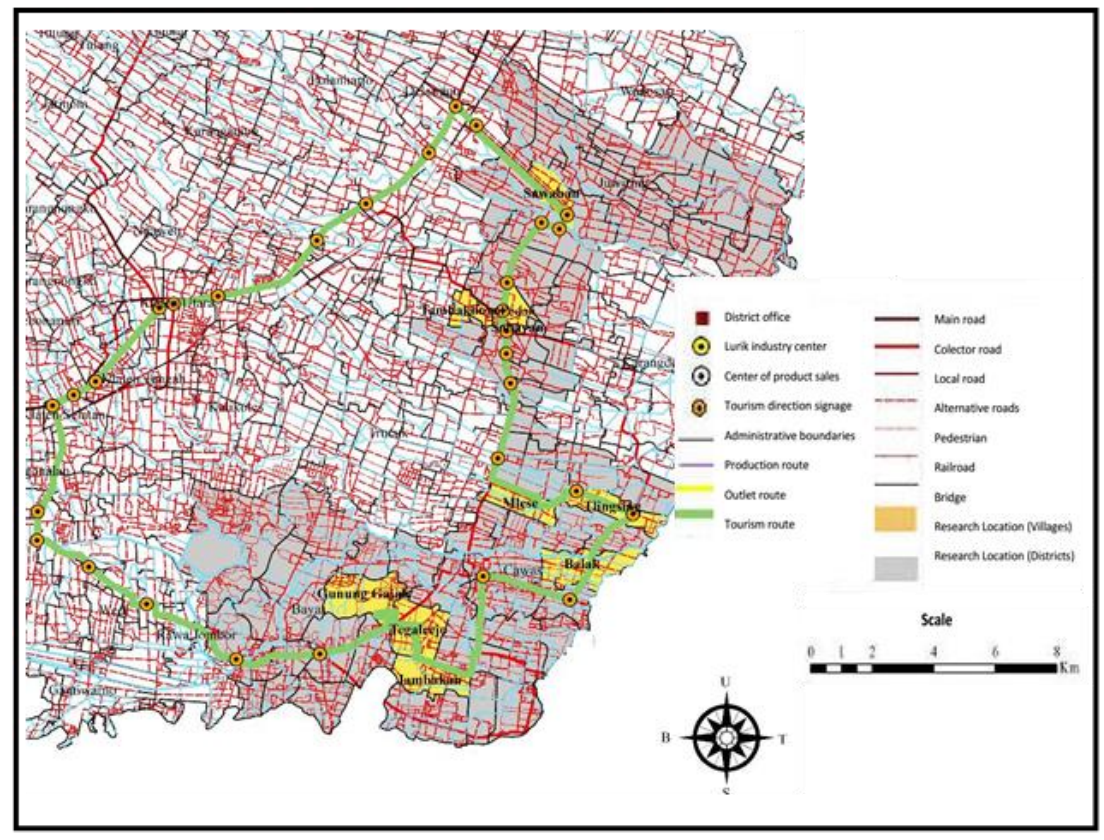

Figure 5. Transportation System of Lurik Industrial Tourism in Bayat, Pedan and Cawas Sub-Districts, Klaten District

\section{RESULT AND DISCUSSION}

\subsection{The Pattern of Industrial Transportation Route}

Based on the analysis of transportation routes in Bayart, Pedan and Cawas Sub-districts, Klaten District on Figure 6 , it is suggested that the pattern of industrial transportation route naturally forms business network pattern in terms of lurik products distribution and sales from one lurik industry into other industries. This is in line with the results of research suggested by Alberti \& Giusti (2012) that the relationship between cultural heritage and regional competitiveness can be developed by the establishment and development of 
clusters through tourism synergy with cultural heritage to enhance regional competitiveness. Therefore, it is necessary to have a cultural policy in accordance with the region's character, so that in its development it can be directed toward the culture industry, small manufacturing, and craft-based production. Just as Grodach et al. (2017) explores two aspects, namely the relationship between the culture industry and the small producers, and the cultural and manufacturing-oriented development within a region. The pattern of Lurik industrial transportation route in Klaten District area, forms a pattern with the orientation of efficiency and independence of lurik products distribution and sales in one lurik industry to or from other lurik industries, it can be recognized in Figure 6.

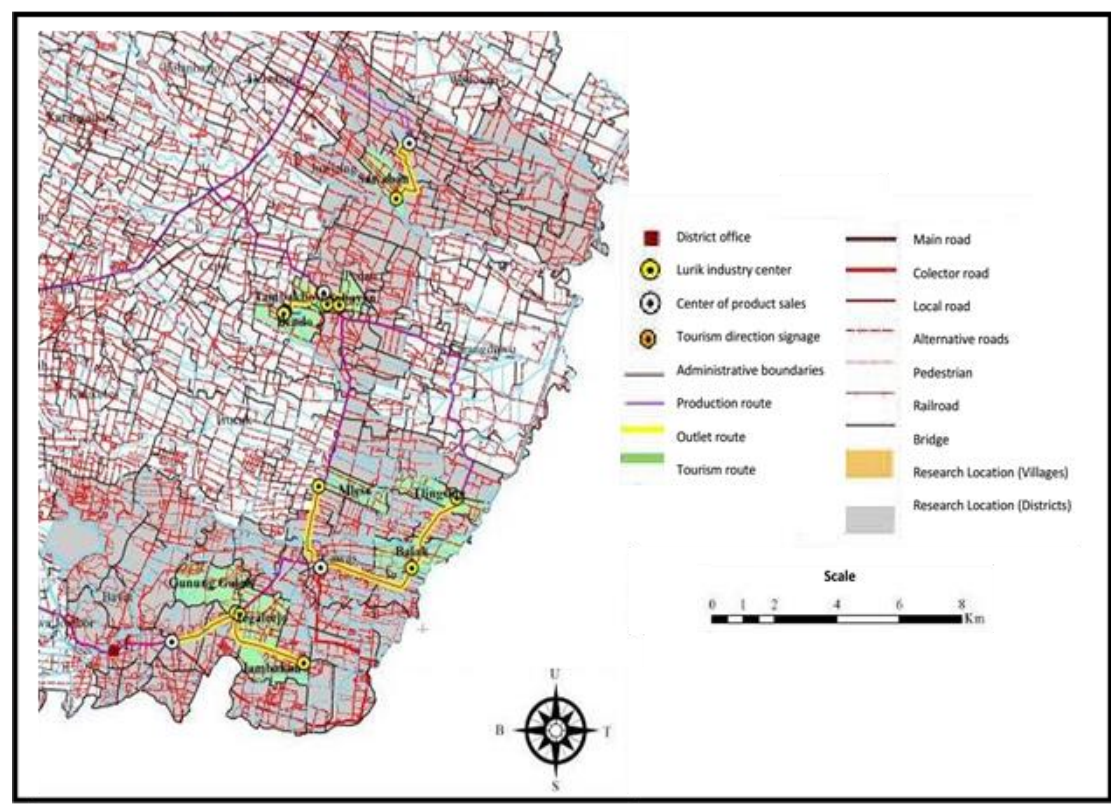

Figure 6. Pattern of Lurik Industrial Transportation Route with the orientation of Efficiency and Independence

\subsection{The Pattern of Tourism Transportation Route}

The study of mapping result of lurik tourism transportation route in Bayat, Pedan, and Cawas Sub-district of Klaten District shows some overlapping parts with transportation route of lurik industries. In some sections, it shows the linkage between one lurik industry and other lurik industries, as depicted in Figure 7, because it has a relationship between semi-finished and finished goods such as clothing, bags, wallets, scarves and other products made of lurik materials. As suggested by Douglass (2016) that the target of economic growth in Asia is pointed out by the emergence of creative communities. Moreover, Richards (2011) proposes that tourism development has creatively occurred through the change of tourism orientation from performance tourism into community's everyday activities in terms of lurik production. This is underpinned by the results of research conducted by Tan et al. (2013) that tourists' creative experiences can occur due to tourists' interactions with environments, business actors, products, services and joint activities. Consequently, this becomes tourism attraction to move from one lurik industry facilities into other lurik industries, until pattern of tourism with inter-industry orientation is formed.

Thus, it can be said that the pattern of lurik tourism network in Bayat, Pedan, and Cawas Sub-districts is naturally formed with inter-industry orientation and supporting tourism facilities. In other words, it is in accordance with the results of research suggested by Bruce Balfour, Michael WP Fortunato, Theodore R. Alter, (2016) that the development of art-based tourism and rural community efforts, has the potential to strengthen interactional networks and encourage community involvement, sense of belonging, entrepreneurship, and creative transformation (Balfour et al., 2018). The existing pattern of tourism transportation routes can strengthen the development of tourism by involving various aspects as proposed by Tan et al. (2013) namely the interaction of tourists with the environment, business actors, products, services, and joint activities. 


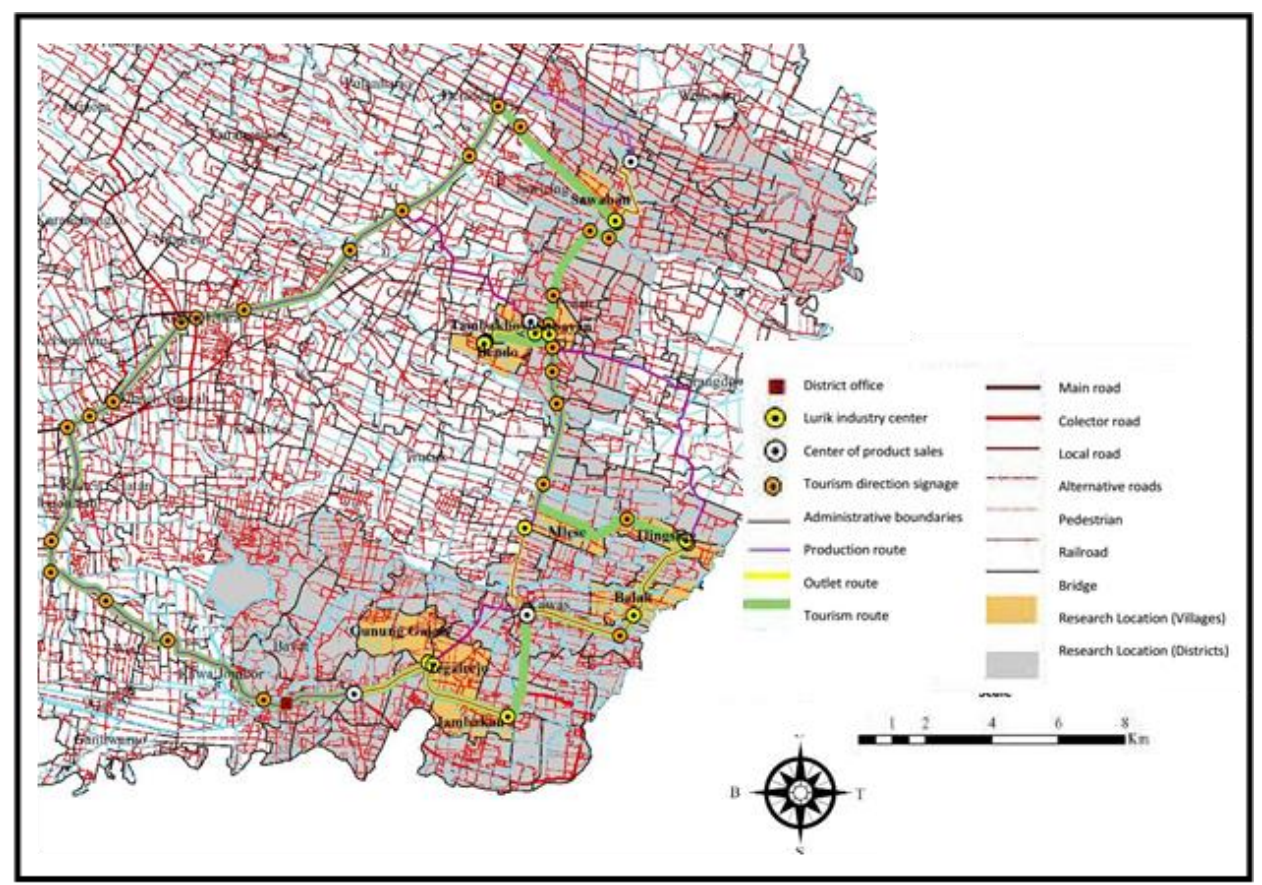

Figure 7. Pattern of Lurik Tourism Transportation Route with Inter-industry Orientation

\subsection{Integration of Industrial Area and Lurik Tourism Transportation}

The pattern of lurik industrial transportation routes in Klaten District area forms a pattern with the orientation of efficiency and independence of lurik products distribution and sales in one lurik industry to or from other lurik industries. Meanwhile, the mapping of lurik tourism transportation route shows some overlapping parts with lurik industry transportation route. The pattern of lurik tourism transportation route in lurik industrial areas in Bayat, Pedan, and Cawas Sub-districts, Klaten District forms a pattern of tourism network with inter-industry orientation. Some parts show interrelationship among lurik industries due to the relationship of semi-finished and finished goods such as clothing, bags, wallets, scarves, and other products to support the development of lurik tourism and industry.

Hence, the established integration can be optimized through the implementation of thematic tourism concept by integrating smoothness, security, and easy access point between industry and lurik tourism. This concept can support the research results of Alberti \& Giusti (2012) namely the formation and development of clusters through tourism synergy with cultural heritage to enhance regional competitiveness. Given the smoothness, security, and ease of industry access and lurik tourism, it is undeniable that the distribution of production and sales of lurik products can be increased so that optimization can be achieved towards the wider tourism development. This is in line with the expressions of Wang et al. (2015) that tourism is closely related to globalization and modernity.

\section{CONCLUSION}

Based on the discussion above, it can be concluded that the pattern of lurik industrial transportation route forms a pattern with the orientation of efficiency and independence of lurik products distribution and sales in one lurik industry to or from other lurik industries. This pattern will finally form the cluster of a lurik industry with interrelationship among industries in accordance to the result of research claimed by Alberti et al. (2012) about tourism synergy and cultural heritage in increasing local competitiveness. Hence, cultural policy adjusted to the characteristics of a certain area is needed. It is similar to the study of Grodach et al. (2017).

Tourists' interaction with environments, business actors, products, services, and joint activities become an attraction to move from one lurik industry facilities to others, so the pattern of tourism network with inter-industry orientation is formed. The result of overlying the pattern of lurik industrial transportation and lurik tourism transportation on some parts indicates the overlapping transportation routes between lurik industry and lurik tourism. It implies that part of routes integrated between industrial route with the 
orientation of efficiency and independence and tourism route with inter-industry orientation can produce the effectiveness of lurik industrial tourism development routes through a lurik industrial tourism conceptbased integration of transportation access. Integration constructed can be optimized through the implementation of thematic tourism concept by combining accessibility, safety and ease of access between lurik industry and tourism. This concept is a scientific enrichment related to the formation and development of industrial clusters as a tourism area. Along with accessibility, safety and ease of access to lurik industry and tourism, a wider development of tourism can be reached.

\section{ACKNOWLEDGMENTS}

The researcher team expresses gratitude to the Urban and Regional Planning Department of Engineering Faculty, Sebelas Maret University and the Research and Development Center of Tourism and Culture of Research and Community Service Institute of Sebelas Maret University who have facilitated the achievement of research funding through the competition of College Prime Research Program of Directorate General of Higher Education. In addition, the researchers thank all of the parties who have contributed towards the research, particularly the Regional Planning and Development Agency of Klaten District.

\section{REFERENCES}

Alberti, F. G., \& Giusti, J. D. (2012). Cultural heritage, tourism and regional competitiveness: The Motor Valley cluster. City, Culture and Society, 3(4), 261-273. [Crossref]

Balfour, B., Fortunato, M. W. P., \& Alter, T. R. (2018). The creative fire: An interactional framework for rural arts-based development. Journal of Rural Studies, 63, 229-239.

Chen, H.-J., Chen, P.-J., \& Okumus, F. (2013). The relationship between travel constraints and destination image: A case study of Brunei. Tourism Management, 35, 198-208. [Crossref]

Douglass, M. (2016). Creative communities and the cultural economy-Insadong, chaebol urbanism and the local state in Seoul. Cities, 56, 148-155. [Crossref]

Gao, J., \& Wu, B. (2017). Revitalizing traditional villages through rural tourism: A case study of Yuanjia Village, Shaanxi Province, China. Tourism Management, 63, 223-233. [Crossref]

Grodach, C., O'Connor, J., \& Gibson, C. (2017). Manufacturing and cultural production: Towards a progressive policy agenda for the cultural economy. City, Culture and Society, 10, 17-25.

Jati, G. P. (2017, July 4). Pariwisata Indonesia Melesat Paling Tinggi se-Asia Tenggara. CNN Indonesia.

Lai, P.-H., Morrison-Saunders, A., \& Grimstad, S. (2017). Operating small tourism firms in rural destinations: A social representations approach to examining how small tourism firms cope with non-tourism induced changes. Tourism Management, 58, 164-174. [Crossref]

Prodjo, W. A. (2017, July 1). Apa Pentingnya ASEAN Tourism Forum bagi Pariwisata Indonesia? Kompas.

Richards, G. (2011). Creativity and tourism. Annals of Tourism Research, 38(4), 1225-1253. [Crossref]

Tan, S.-K., Kung, S.-F., \& Luh, D.-B. (2013). A Model of Creative Experience in Creative Tourism. Annals of Tourism Research, 41, 153-174. [Crossref]

Todaro, M. P., \& Smith, S. C. (2012). Economic development 11th edition.

Wang, D., Niu, Y., Lu, L., \& Qian, J. (2015). Tourism spatial organization of historical streets--A postmodern perspective: The examples of Pingjiang Road and Shantang Street, Suzhou, China. Tourism Management, 48, 370-385.

Wong, E. P. Y., Mistilis, N., \& Dwyer, L. (2011). A model of Asean collaboration in tourism. Annals of Tourism Research, 38(3), 882-899. [Crossref] 